\title{
Effectiveness of the Leadership of Schools and Work Motivation on Teacher Performance SMP Negeri Sungai Pinang Districts Ogan Ilir Regency
}

\author{
Jausar $^{1 *}$, Syarwani Ahmad ${ }^{2}$, Achmad Wahidy ${ }^{2}$ \\ ${ }^{\text {l} S M P ~ S u n g a i ~ P i n a n g, ~ S o u t h ~ o f ~ S u m a t e r a, ~ I n d o n e s i a ~}$ \\ ${ }^{2}$ Universitas PGRI Palembang, Indonesia \\ *Corresponding author. Email: sitimunajah970@gmail.com
}

\begin{abstract}
The aim of this analysis is to define and describe the effect of principal leadership effectiveness and work motivation on teacher performance, as well as to assess and partially describe the effect of principal leadership effectiveness and work motivation on teacher performance. This study was carried out at the Sungai Pinang District State Junior High School in Ogan Ilir Regency. This study's sample consisted of 63 teachers, and data were gathered through evaluation, questionnaires, and documentation. The prerequisite research test, multiple linear regression test, and multiple correlation test were used to analyze the collected data. The study's findings suggest that the effectiveness of principal leadership (X1) and job motivation (X2) have a positive impact on teacher performance (Y), and that the effectiveness of principal leadership (X1) and work motivation (X2) have a positive effect on teacher performance at the same time (Y).
\end{abstract}

Keywords: Leadership Effectiveness, Motivation, Performance

\section{INTRODUCTION}

The Indonesian government, in an effort to improve education for its citizens, continuously carries out various activities and provides supporting facilities, including the enactment of Law no. 14 of 2005 on teachers and lecturers.

The collected data was analyzed using the prerequisite analysis test, multiple linear regression test, and multiple correlation test. The study's results indicate that the effectiveness of principal leadership (X1) and job motivation (X2) have a positive impact on teacher performance $(\mathrm{Y})$, and that the effectiveness of principal leadership (X1) and task motivation (X2) both have a positive impact on teacher performance (Y) [1]. The role of the principal is very strategic, so three skills are needed, namely conceptual skills, human skills, and technical skills. These three skills suggest that a school principal must be able to: (1) manage and understand the school, (2) work together with people in his environment, and (3) motivate and lead his subordinates [2].

The impact of the principal's leadership effectiveness on teacher success in the context of developing a school environment that can either promote or impede the effectiveness of teacher work [3].
Motivation is a personality trait that encourages an individual's willingness to perform specific tasks in order to achieve an objective [4].

From this description, this research is entitled "Effectiveness Of The Leadership Of Schools And Work Motivation On Teacher Performance Junior High School Sungai Pinang Districts Ogan Ilir Regency”.

\section{METHODS}

The methods used by researchers to gather research data are referred to as research methods [5]. Research methods are scientific methods for gathering data for particular purposes and applications. The scientific method denotes that research practices are based on scientific characteristics such as rationality, empiricality, and systematicity [6].

\section{RESULTS AND DISCUSSION}

The questionnaire that will be used to collect data on leadership effectiveness, work motivation and teacher performance will refer to Likert scale [7].

Based on data from the average value of the success variable predictor $(\mathrm{Y})$, the performance has an average value of 4.1 , which is in the good category, and the principal leadership effectiveness variable $\left(\mathrm{X}_{1}\right)$ has an 
average value of 4.0, also in the good category. job motivation variable $\left(\mathrm{X}_{2}\right)$ indicates an average value of 4.0, which is in the Positive category in the range 3.40 4.19 [8]

According to the normality test performance, the significant value of the principal's leadership effectiveness component was 0.143 , work motivation, 0.205 , and 0.480 performance, so it can be concluded that the value is normal because the significant value is $>0.05$.

From the regression equation, it can be described as follows, the value of 33.470 means that the value of the performance (Y) when the principal's leadership effectiveness $\left(\mathrm{X}_{1}\right)$ is equal to zero or constant is 33.470 . This value indicates that performance is greatly influenced by the leadership variable of the principal.

From the regression equation, it can be described as follows, the value of 32.704 means that the value of performance when the value of work motivation is zero or constant is 32.704. this value indicates that performance is very influenced by work motivation variables.

Based on the Model Summary performance, the results of multiple correlation analysis $(\mathrm{R})$ yielded a $\mathrm{R}$ number of 0.627 , which falls into the strong group. Because the multiple correlation value is between 0.60 0.799 , it is possible to infer that there is a substantial relationship between principal leadership $\left(\mathrm{X}_{1}\right)$ and job motivation $\left(\mathrm{X}_{2}\right)$ on success $(\mathrm{Y})$ in Junior High School Sungai Pinang District, Ogan Ilir Regency.

\section{1) Effect of Principal Leadership Effectiveness on Performance in Junior High School Sungai Pinang District, Ogan Ilir Regency.}

In the descriptive analysis, the average score of the principal's leadership from the statement of item number one to the statement of item number twenty-five, obtained an average result of 4 or $79.20 \%$ of respondents who stated that the leadership of the principal in Junior High Scholl Sungai Pinang District, Ogan Ilir Regency is in the good category.

For inferential analysis demonstrates that the principal leadership variable has a major impact on teacher output in part, where from the partial test results ( $t$ test) the significance of $t$ is 0.004 . This means that the motivation in carrying out the duties and roles has been carried out properly or as expected.

The observation results obtained that the principal leads very democratically, where the leader in carrying out his programs always consults or asks opinions from his subordinates.

Meanwhile, in terms of documentation, for example, the principal's teacher assignment division sk archive is very wise in making decisions tailored to the needs of the teacher, in which teachers are still given a teaching load of at least 24 hours of lessons per week in order to disburse the teacher professional allowance (certification). Then the remaining teaching hours are given to permanent teachers who have not been certified and teachers who are not permanent (honorary). Furthermore, the respondent saw a photo of the list of Minimum Completeness Criteria values in the teacher's room, according to the vice principal in the curriculum field, explaining that the above was determined by the teacher in the field of study concerned based on an average of the basic competency indicators adjusted to the level of difficulty characteristics of the material in the subject.

\section{2) Job Encouragement and Teacher Success in SMP Negeri Sungai Pinang District, Ogan Ilir Regency}

From the results of the answers to the questionnaire of respondents both on the statement item number one to the statement item number twenty-five obtained a score of 4.0, placing it in the positive group According to the findings of the inferential study, partially job motivation has a major impact on the performance of teachers at Junior High School Sungai Pinang District, Ogan Ilir Regency, where the partial test results (t test) of significance $t$ is 0.004 .

Based on the results of observations that the impact of motivation in an effort to create work harmonization with fellow teachers and employees in order to maintain integrity and cohesiveness in schools in order to improve teacher performance at Junior High Scholl Sungai Pinang District, Ogan Ilir Regency is very supportive in achieving performance, because teachers must be able to nurture attitudes. democratic and full of respect for fellow teachers in order to achieve the formation and guidance of students carried out by the collaboration of one teacher with other teachers.

3) The Impact of Principal Leadership Effectiveness and Job Encouragement on Teacher Efficiency in the SMP Negeri Sungai Pinang District of Ogan Ilir Regency

Data analysis using multiple linear regression formula or commonly called the F-test, the analysis results show that the calculated $\mathrm{F}$ value is 17.786 . While the value of significant $F$ is 0.000 , where the value is less than the value of accuracy $=0.1(\mathrm{Pv}<)$, it means that there is Principal Leadership Effectiveness (X1) and Work Motivation (X2) have a major impact on results (Y). The Principal should be capable of carrying out inventions, be able to direct all stakeholders and the school as an education institution [9]. The Principal has the authority and policies to enhance the standard of education as a leader [10].

Apart from the results of the questionnaire, it was also supported by the results of observations where the performance of teachers at the unior High Scholl Sungai Pinang District, Ogan Ilir District had carried out their duties well. This can be seen from: 
a. The instructor adhered to the existing educational standards throughout the teaching and learning period, namely using the 2013 curriculum.

b. Teachers are disciplined in carrying out their duties as educators.

c. The teacher has motivated students to study harder.

d. The teacher also uses learning strategies, the use of media and learning resources.

e. The teacher has arranged an orderly administration.

\section{CONCLUSION}

Mainly focused on the outcome of the review of data, can be explained as follows: 1) the efficacy of school principals' leadership has a positive impact on teacher success in the Sungai Pinang District Junior High School, Ogan Ilir Regency. This demonstrates that the greater the principal's leadership effectiveness, the higher the teacher efficiency; 2) job motivation increases teacher efficiency at Sungai Pinang Junior High School in Ogan Ilir Regency. This demonstrates that the higher the job motivation, the better the teacher's efficiency, and 3) the efficacy of the principal's leadership and job motivation, when combined, have a positive impact on teacher success in the Junior High School Sungai Pinang District, Ogan Ilir Regency. This illustrates that the more successful the principal's leadership is and the greater the desire to cooperate, the higher teacher performance would be.

\section{ACKNOWLEDGMENT}

Our deepest gratitude goes to Teachers in SMP Sungai Pinang, Chancellor of Palembang PGRI University, Director of the Postgraduate Program of PGRI Palembang University and the Education Management Study Program of PGRI Palembang University, who have supported us in doing this extraordinary thing. This project is funded independently. We also want to thank our Education Management friends who helped us a lot in a short time frame to complete this project.

\section{REFERENCES}

[1] Wahjosumidjo. (2011). Kepemimpinan Kepala Sekolah [Principal Leadership]. Jakarta: Rajawali Press.

[2] Pandji, A. (1992) Psikologi Kepemimpinan [Psychology of Leadership]. Jakarta: Penerbit Rineka Cipta.

[3] Uben \& Hughes. (2012). Motivasi, Kepemimpinan, dan Efektivitas Kelompok [Motivation, Leadership, and Effectiveness]. Jakarta: Rineka Cipta.
[4] Handoko. (2001). Manajemen Personalia dan Sumber Daya Manusia [Personnel and Human Resources Management]. Yogyakarta: BPFE.

[5] Arikunto. S. (2010). Prosedur Penelitian Suatu Pendekatan Praktek [Research Procedure A Revised Edition Practice Approach]. Edisi Revisi. Jakarta: Rineka Cipta.

[6] Sugiyono. (2009). Metode Penelitian Kuantitatif Kualitatif \& RND [Qualitative \& Quantitative Research Methods RND]. Alfabeta, Bandung.

[7] Riduwan. (2011). Pengantar Statistika untuk Penelitian Pendidikan, Sosial, Ekonomi, Motivasi, dan Bisnis [Introduction to Statistics for Educational, Social, Economic, Motivational, and Business Research]. Bandung: Alfabeta

[8] Sudjana. (2006). Metode Statistika [Statistical Methods]. Bandung: Tarsito.

[9] Andriani, S., Kesumawati, N., \& Kristiawan, M. (2018). The Influence of the Transformational Leadership and Work Motivation on Teachers Performance. International Journal of Scientific \& Technology Research, 7(7).

[10] Asvio, N., Yamin, M., \& Risnita. (2019). Influence of Leadership Style, Emotional Intelligence and Job Satisfaction toward Organizational Commitment (Survey at SMA Muhammadiyah South Sumatera). International Journal of Scientific \& Technology Research 8 (8). 